\title{
Financial Performance Analysis of Corn-based Ethanol Enterprises in the U.S.
}

\author{
Allan P. Bacho \\ Agriculturist II \\ Department of Agriculture, Regional Office 10, Cagayan de Oro City, Philippines \\ E-mail: allanbacho@gmail.com \\ Olga I. Murova (Corresponding author) \\ Associate Professor \\ Department of Agricultural and Applied Economics, Texas Tech University, USA \\ Tel: 806-843-3257Ｅ-mail: olga.murova@ttu.edu
}

Received: March 27, 2017 Accepted: April 21, 2017

doi:10.5296/ber.v7i1.10982ＵRL: https://doi.org/10.5296/ber.v7i1.10982

\begin{abstract}
The objective of this study is to examine the state of financial conditions of the corn-based ethanol enterprises in the U.S. from 2009 to 2014. Ethanol enterprises are categorized as small, those producing up to 50 million gallons per year (MGY) and large producing between 50 and 100 MGY. Panel data from the annual financial reports submitted to the Securities and Exchange Commission (SEC) are used to calculate the financial ratios of profitability, asset turnover, leverage, liquidity and operating margin. Results show that the corn-ethanol enterprise is moving into the direction of positive returns of investment. Associated factors for the profitability are found to be operating margin ratio, liquidity, leverage ratio, and subsidy. Findings of this study have an implication to the development of the cellulosic ethanol enterprise, which suggests the utilization and valuation of its co-products for revenue generation to improve economic financial success.
\end{abstract}

Keywords: Financial performance, Corn-ethanol, Enterprise, Profitability, Leverage, Ethanol subsidy

Equal authorship in this research. 


\section{Introduction}

The rise of ethanol production has increased agribusiness opportunities for corn farmers in the United States. The ethanol industry is relatively new agribusiness venture that started in the late 1970s with the formalization of legislative support from the government. The rise of the ethanol industry was attributed to unstable supply and high prices of foreign oil due to conflicts in the Middle East, and the ban for gasoline oxidative additive of methyl tertiary butyl ether (MTBE), with ethanol being used as an alternative (Eidman, 2007; Tyner, 2007).

More ethanol enterprises have been built by farmer's associations, cooperatives, and private investors in the last decade and that contributed to the increase in ethanol production (Figure 1). Ethanol industry data show that the establishment of ethanol enterprise plants had quadrupled between 1999 and 2014. In 2014, there were 210 ethanol enterprise plants established with total nameplate production capacity of 15,047 MGY (RFA, 2014). Iowa is producing around $25 \%$ of ethanol, Nebraska $-11.2 \%$, Illinois $-10.4 \%$, and the rest of the states produce around 53\%. This distribution of plants show that ethanol enterprises located around the supplies of corn with the Midwestern states producing most of the ethanol, however ethanol's biggest markets are the West and the East coastal states. (DOE, 2010; Westcott, 2007).

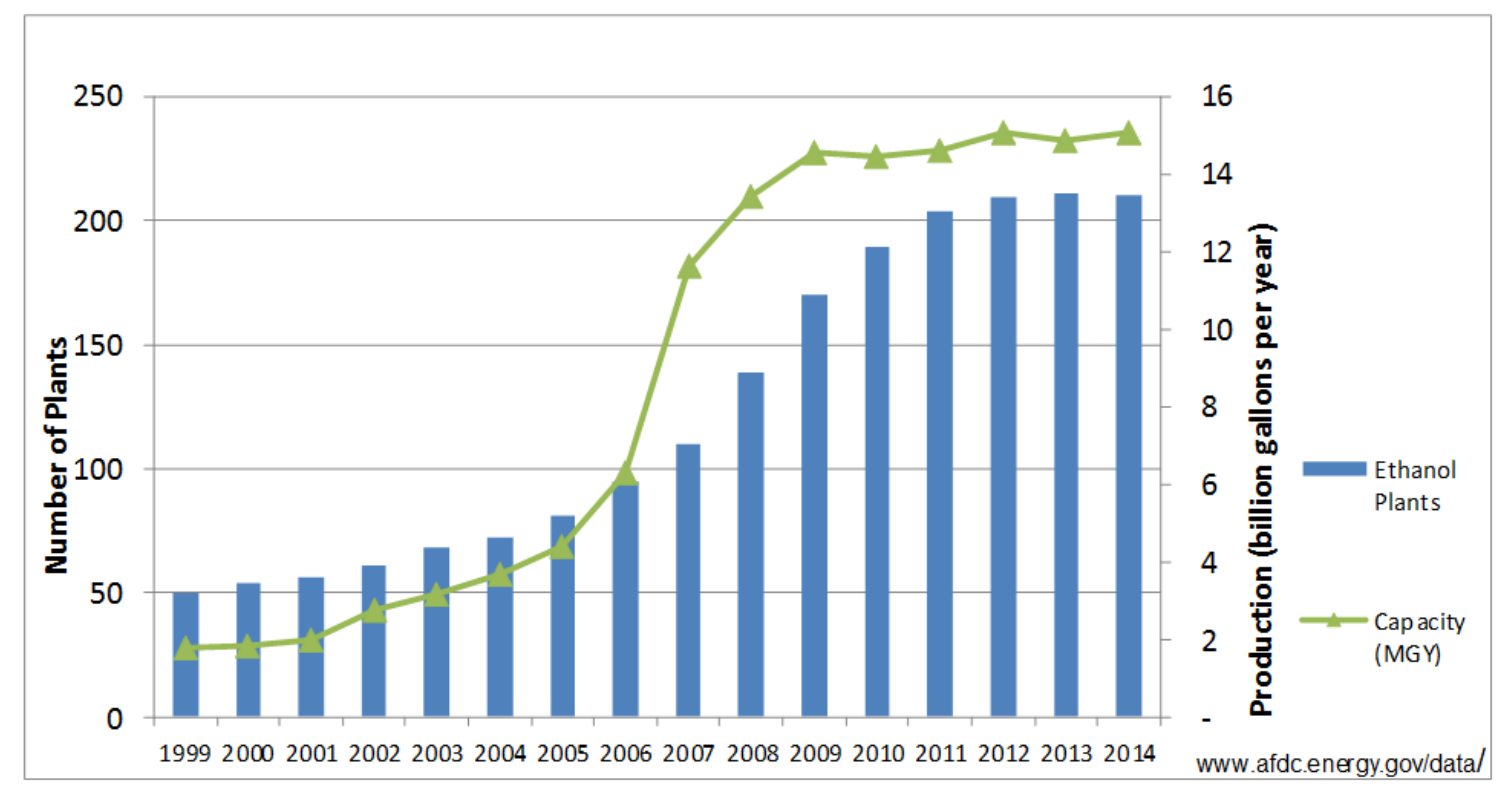

Figure 1. U.S. Ethanol Plants and Capacity, 1999-2014

Some studies related to ethanol enterprise consider the feasibility of its production (Klose et al., 2003), and investment decisions to expand, exit or to mothball ethanol plant operation (Schmit et al., 2009). The effect on facility size and optimal levels (Gill et al., 2003), response of corn acreage to ethanol plant (Fatal, 2014; Feng and Babcok, 2008), and the effect on the competition of crops and land use for corn (Simla et al., 2007) are also estimated. More so, estimation on the analysis of the ethanol production profitability (Hofstead, 2015), and market analysis of ethanol capacity (Cai and Stiegert, 2014) are also observed in the recent economic literature. 


\subsection{Framework of Financial Performance Analysis of the Ethanol Enterprise}

Financial analysis as a basis of performance is commonly used in analyzing business firms, in agriculture, and in agribusiness sector. For example, the profitability study of the engineering and construction firms showed that size has no effect on profit, but larger firms tend to be more diversified in nonrelated businesses (Yee and Cheah, 2006). Ratios of profitability and leverage were applied to compare the financial performance of state and publicly-owned firms. Results show that public firms are less profitable and incur higher liabilities than the private firms (Dewenter and Malesta, 2001). The financial performance ratio on the satisfaction of employees' performance in a bank is also applied, but results provide no significant relationship (Johnson et al., 2009). Following these examples on the use of financial performance in business, Wu and Ho (1997), cited the findings of Lev (1969), have investigated the use of financial ratios as a yardstick for industry-wide or strategic performance. The ratios of equity to total debt, sales to asset, net operating income to total asset, quick ratio were applied and it was found that ratio movement is due to changes in external shocks or an active adjustment by strategic management toward the desired target. More so, the sales to inventory, and net operating income to total asset ratio suggest for the additional financial assessments of the industry.

In the U.S., the Department of Agriculture conducted the "Financial Performance of U.S. Commercial Farms, 1991-1994". This comprehensive report used ratios of liquidity, solvency, efficiency, and profitability to evaluate the condition of U.S. commercial farms. Some of the findings are: commercial farms were more profitable in 1994 than in 1993, average liquidity (current asset to current liability) ratio was between 2.4 to 2.9 , and about 36 percent of the farms received direct government commodity payments (USDA, 1994). Hishman and Johnson (1998) also used financial performance to evaluate the determinants of commercial dairy farm operation. This study employed net income as a measure of profit and found that liability, the size of the operation, and labor cost are associated factors for profit generation.

Using a standardized financial analysis protocol developed by the Farm Financial Standard Council (FFSC), Clark et al. (2001) applied financial analysis performance for the Texas High Plains cotton crop using the Standardized Performance Analysis-Multiple Enterprise (SPA-ME) software. Significant to this study, return on asset (ROA), return on equity (ROE), and operating margin were used as profitability measures. Some findings of this study indicate that covered farms had negative ROA, ROE and operating margin. This was attributed to negative net operating income which was a result of paying more in interest expense on borrowed funds than investing in operation in 1995. However, cotton industry made a turn-around of its condition in 1996 when debt was used profitably to earn positive return. These financial conditions were reflected in the regional analysis where a large increase in ROA and ROE was observed in 1996 due to increasing crop yield.

Moreover, financial performance measure was also used to assess the training effectiveness in dairy industry, but the findings showed that training has no significant impact on the financial performance (Smith et al. 2003).

Lerman and Parliament (1991) also applied financial analysis to study the effect of size and 
industry on agricultural cooperative performance. They found the size effects for large and small agricultural cooperative were significantly different in asset turnover (sales to asset), liquidity (quick ratio), and profitability (return on equity) ratios, but not in leverage (debt to equity) across dairy, food, grain, and supply industries.

Soboh et al. (2009) posited the critique that economists studying cooperative performance focus on profit-maximizing objective and omit the other goals that reflect the duality of cooperative purpose: serving members' benefits and firm profits. Application of the firm theory which assumed the goal of the cooperative as a profit-maximizing agent had failed to incorporate the combined benefits to members and firm profit. To address the second goal of cooperative's purpose, many empirical studies employed the financial ratios or the efficiency measurement techniques for comparison of cooperatives. However, number of these studies is limited due to difficulty in obtaining relevant data.

\subsection{Ethanol Enterprise and the Subsidy}

Several studies have been conducted to estimate the effect of subsidy on the ethanol industry using technical economic assumptions in the economic analysis. The purpose of government subsidy is to promote production and/or consumption (Tyner and Quer, 2006). The government subsidy program's development objective was established through policy issuances which define the parameters of the subsidy.

The history of the U.S. ethanol subsidy legislation policies from 1978 to 2005 was presented by Tyner (2007). Ethanol subsidies started with the Energy Tax Act of 1978 when ethanol was blended with gasoline and called "gasohol," subsidy started at $\$ 0.40$ per gal as an excise tax. It was raised to $\$ 0.50 / \mathrm{gal}$ in 1983 , added 10 cent more in 1984 at $\$ 0.60 /$ gal, pulled-down in 1990 at $\$ 0.54 /$ gal. Since 1990 , the excise tax exemption was reduced further: $\$ 0.53 / \mathrm{gal}$ in 2001, \$0.52/gal in 2003, \$0.51/gal in 2005 and \$0.45/gal in 2009 when the Volumetric Ethanol Excise Tax Credit (VEETC) had expired in 2011(Miller and Coble, 2011). These policies support ethanol subsidy regardless if it was produced from corn or other raw materials.

The current functional biofuel policy is the Energy Independence and Security Act (EISA) of 2007 which covers other sources of ethanol production categories: (1) biomass-based diesel, (2) cellulosic advanced biofuel, (3) other advanced biofuels, and (4) conventional biofuel permitting the corn-based ethanol production (Tyner, 2013). The act is implemented by the Environmental Protection Agency (EPA) which formulates the mandated Renewable Fuel Standard volume for each of the biofuel category covered in the EISA. With its mandated volume quota, it restricts the corn-based ethanol to expand its production capacity at an annual production mandate of 15 billion gallons per year by 2022. However, recent reports stated that the EPA has failed to determine the annual RFS volume on time (Taxpayers for Common Sense, 2015).

Other than the EPA, the biofuels and biomass subsidy programs were also implemented by the U.S. Department of Agriculture (USDA) through the Farm Bills (2002, 2008, and 2014) under energy title, Department of Energy (DOE) under the Energy Policy Act of 2005, and 
the Department of Treasury under the production tax credit (PTC).

Reports from the Taxpayers for Common Sense (TCS) in September 2015 showed that under the Farm Bill and Trade Titles, the total corn ethanol subsidies reached \$190.2 million from 2009-2014. These were implemented in a variety of terms from grants and loans, loan guarantees, reimbursement payments, and solicitations from the USDA. Under the Clean Cities or State Energy Programs (SEP) of the DOE, 18 states were covered with a total cost of \$252.65 million from a variety of state incentive program initiatives. Under the Treasury Department, the support was on the use of corn for biodiesel production at $\$ 1$ per gallon under the Volumetric Biodiesel Excise Tax Credit and Renewable Biodiesel Tax Credit. With these huge amounts of allocated subsidies, the TCS has opposed the policies and implementation of government subsidies as public expenditure.

Thus, the objective of this study is to examine the state of financial performance of corn-based ethanol enterprises in the U.S. It seeks to determine the factors contributing to the profitability of ethanol enterprise operation. More so, the other types of ethanol enterprises can benefit from the findings of this study by improving the financial success of their operation.

However, factors that may influence the profitability measure from the market such as the price of ethanol and other external pressures on the ethanol industry were not considered in this paper. This limitation is provided by the nature of data source. This paper uses empirical data from the standard financial ratios to examine the corn-based ethanol enterprise financial performance. Annual financial statements reported to the Securities and Exchange Commission (SEC) do not contain quantity and prices of inputs and outputs.

\section{Data and Methodology}

Selection of the ethanol enterprises to be included in this study was based on the list from the leading on-line ethanol industry magazine, "Ethanol Producer Magazine". As of October 06, 2015, the website listed a total of 216 ethanol plants with total nameplate capacity of 15505 billion gallons per year. Using the industry data, this study categorized small enterprise plant as a plant producing up to 50 million gallon per year (MGY), and large between 50 and a 100 MGY and super-large plant with production over a 100 MGY.

The on-line link of the company website was searched using the on-line ethanol magazine website for its history of operation, and annual financial statements reported to the Securities and Exchange Commission (SEC). All annual reports submitted to the SEC are deposited on the EDGAR archives under the Form $10-\mathrm{K}$ file. The $10-\mathrm{K}$ form is the company's annual report which uses prescribed accounting principles and methods for firms where shares are sold to the public on the American stock exchange (Wolfe, 1994).

Resulting data collected from the EDGAR archives generated 15 ethanol companies: 6 companies representing the small capacity plants, 6 representing large companies, and 3 representing super-large companies. Further review of these companies showed detailed characteristics of the company structure, scope of operation, and plant location.

Overall selection of the representative ethanol enterprises was based on the following criteria: 1) corn-based ethanol operation in the U.S., 2) single-plant operation, not branched operation 
as branched operation has a consolidated financial reporting, 3) ethanol enterprises which listed ethanol as primary product, excluding vertically integrated companies with multiple operations in corn commodity trading and marketing, ethanol marketing, gasoline blending, and gasoline stations, and 4) covers only financial data from 2009 to 2014 since most large plants were established after 2009.

Using the above criteria, the super-large plants were taken out in the database. The primary reason is that most super-large ethanol enterprise plants have complex operation in several businesses and its financial performance cannot be ascertained to ethanol revenue as it is often consolidated to the larger business operation of the company.

By narrowing the plants included in the analysis, it resulted to an equal representation of 6 small and 6 large corn-based ethanol enterprises. This dataset covers the period from 2009 to 2014 and generated 72 observations. Thus, the database represents ethanol plants in operation and the unit of analysis in this study is at the enterprise firm level.

\subsection{Financial Statements and Ratios}

The foundation of the data used in this study is based on the Audited Financial Reports which follow the Generally Accepted Accounting Practices (GAAP). The financial statements used by the Farm Financial Standard Council (FFSC, 2015) in the agriculture sector also complies with the GAAP with modification relevant to the agriculture industry. The foundation of the financial analysis is based on the assumption that total assets are represented by total liabilities plus total equity (Clarke, 2009; Jablonsky and Barsky, 2001).

Financial ratios utilized in this study examine the performance of the ethanol enterprises. These financial ratios are used to assess the utilization of its economic financial resources as expressed by the ratios of profitability, return on equity, asset turnover, liability, leverage, and operating income (Table 1).

Profitability ratio or the return on equity is one of the two most representative financial ratios for return on investment to stakeholders. It represents the efficient utilization of investment fund to generate net income (White et al., 1998; Placencia et al., 1989). The higher the ratio, the higher the net income generated than the equity invested.

Asset turnover is one of the most representative financial ratios for capital turn-over. It measures how well a company converts its assets into revenue (Clarke, 2009; White et al. 1998). The higher the ratio, the higher the revenue generated from its asset value.

Leverage ratio measures the debt-to-equity proportion of the ethanol enterprise. It indicates the financial risk of the enterprises in using borrowed money to run the business (Clarke, 2009; Jablonsky and Barsky, 2001). The lower the ratio, the better the enterprise gets out from debt in proportion to equity investment. 
Table 1. Financial ratio measures of performance

\begin{tabular}{|l|l|l|}
\hline Performance criteria & Ratio & Definition \\
\hline Profitability & Rate of return on equity & $\begin{array}{l}\text { Net Income* } \\
\text { Total Equity }\end{array}$ \\
\hline Efficiency & Asset Turn-over & $\begin{array}{l}\text { Total Revenue } \\
\text { Total Asset }\end{array}$ \\
\hline Leverage & Debt to equity & $\begin{array}{l}\text { Total Liabilities } \\
\text { Total Equity }\end{array}$ \\
\hline Liquidity & Quick ratio & $\begin{array}{l}\text { Current Asset } \\
\text { Current Liability }\end{array}$ \\
\hline Operating Income Margin & Operating Income & $\begin{array}{l}\text { Operating Income } \\
\text { Total Revenue }\end{array}$ \\
\hline
\end{tabular}

*Net income is before-tax rate as observed in the submitted annual financial reports of these companies.

The liquidity ratio using the current asset over current liability and is one of the two most representative financial ratios for short-term liquidity. Current refers to the payable requirement for a year from the easily converted asset to pay the existing liability. A higher ratio suggests that an enterprise is able to meet its current payable within a year. The generally accepted ratio is greater than 1, but it can vary by industry (White et al., 1998).

Operating margin ratio is calculated from the reported operating income and total revenue. It measures the efficiency of the operation to generate internal income from the operation. It provides information on enterprise profitability from the operation of its core business, excluding the effects of its income from affiliates or asset sales, and interest expense (White et al., 1998).

The benefit of using a set meaningful financial ratios is the reduction of ratios to be computed and monitored. For example, liquidity ratio is highly used by enterprise and corporate managers to know if their current asset can immediately respond to payables for the operation of an enterprise (Soboh et al., 2009; White et al., 1998).

\subsection{Factors Associated with the Profitability Measure of Ethanol Enterprise Operation}

Soboh et al. (2009) posited two categories of the analyses of empirical data on the financial performance of agricultural enterprises. First category of analysis is to evaluate financial performance using ratios that represent the ability and the efficiency of equity to generate returns, i.e. looking at profitability and efficiency. The second category is concerned with the nature of financing an equity capital or capital financing (Soboh et al., 2009; Lerman and Parliament, 1990).

The measure of profitability in this study is based on the set of available variables describing operation of a corn-based ethanol enterprise. One variable in the assessment of the profitability measure is age ( $\beta_{1}$ Age) as represented by years in operation. It is postulated that as plant years in operation increases, the operation is becoming more efficient.

Corn is the major input in the production of ethanol and its co-products. Since the annual financial statements do not contain the actual price and quantity of corn used, the USDA average annual corn price for states where plants are located is used. Using the corn price 
instead of quantity, it was postulated that the corn price represents the cost technology efficiency in ethanol production. Corn price plays a role of an indicator of total revenue generation, since it represents a cost of the primary input.

The ethanol enterprise plants are classified as small with up to $50 \mathrm{MGY}$ ethanol production capacity and as large with production capacity between 50 and 100 MGY. This study employs the dummy variable to represent ( $\beta_{3}$ DumSz1) small enterprise plants. The economies of scale principle suggests that small capacity plants have lower profitability ratio than large capacity plants.

The operating margin ratio $\left(\beta_{4} \mathrm{OpMaR}\right)$ represented a plant internal operating efficiency, as it is the income generated from efficient operation of the enterprise plant. It is expressed as percent of operating income over total revenue. Higher operating margin means less plant operation shut down, efficient use of corn to convert to ethanol and its co-products, and the efficient use of energy.

The financial ratios employed in this study selected based on meaningful function and expressed in percentages to determine its contribution to the profitability measure. One of these ratios is the percent asset turnover ( $\beta_{5}$ AsTurnO) which contributed to the profitability measure in the asset function of the balance sheet equation. Higher asset turnover means better financial performance as it generates higher total revenue from the asset utilization.

The leverage ratio $\left(\beta_{6} \mathrm{Lev}\right)$ measures the percent on the magnitude of liability incurred over its equity value. The leverage ratio is postulated to decline as liabilities have been paid-up during the years of operation.

The liquidity ratio is expected to increase as current liabilities have been paid-up for the year. The percent liquidity ( $\beta_{7}$ Liquidity) ratio is an assessment of plant' capability to meet current payables.

Horrigan (1965) mentioned that only few financial ratios are needed to effectively capture vital information on the financial condition of the enterprise.

Subsidy ( $\beta_{8}$ Subsidy) measures the contribution of reported government support received by the ethanol enterprise. Subsidy is postulated to improve production efficiency and contributes to asset value of the enterprise.

Finally, profitability ratio is measured as the percent of net income over total equity or the return on equity as dependent variable. This ratio is selected for measuring how much net income is generated from the equity invested. Using the balance sheet, the ratio is the net effect of reducing liabilities, building up the asset value and contributing to the investors' equity financial portfolio.

Relationship between profitability and all other variables is presented by the following multiple regression model:

$$
\begin{array}{r}
\text { Profitability }=\alpha+\beta_{1} \text { Age }+\beta_{2} \text { CornPrc }+\beta_{3} \text { DumSz1 }+\beta_{4} \text { OpMaR }+\beta_{5} \text { AsTurnO }+ \text { B }_{6} \text { Lev }+ \\
\beta_{7} \text { Liquidity }+\beta_{8} \text { Subsidy }+\mu
\end{array}
$$




\section{Macrothink}

Business and Economic Research

ISSN 2162-4860

2017, Vol. 7, No. 1

The error term $(\mu)$ or the disturbance is an unobserved random term that does not depend on the value of explanatory variables (Mirer, 1995). Regression is estimated using panel data from the annual financial reports of the ethanol enterprise plants. It is expected that panel data can possibly have problems of collinearity, heteroskedasticity, and autocorrelation of the model (Wang and Atabay, 1994). White et al. (1998), cited Horrigan in 1965, on the presence of collinearity in using the financial ratios from a financial reports. Thus, the presence of all abovementioned problems in the estimated model was tested in the OLS regression with the Variance Inflation Factor (VIF) for collinearity test, White Test for heteroskedasticity, and Durbin-Watson for autocorrelation using the SAS 9.4 version.

\section{Results and Discussion}

The financial characteristics of corn-based ethanol enterprises in the U.S. are described based on enterprise capacity through plant size (Table 2). Using 2014 as the end year reference period, large plants have 6.2 years and small enterprise plants have 9.0 years in an average of plant operations. This indicated that the average large plants were newly operational in 2009 as the data is based from 2009 to 2014 or the 6-year period.

Financial characteristics of corn-based ethanol enterprises indicate that the total asset build-up for large enterprise capacity plants is $\$ 153.4$ million and $\$ 82.0$ million for small plants, or 1.89 times higher for large plants than for small plants. Part of this asset build-up is the infusion of equity from investors with an average of $\$ 89.6$ million for large plants capacity and \$51.3 million for small plants capacity. As more asset and equity were required for large plants, its operational total liability is 2.05 times higher than the small plants at $\$ 63.7$ million compared with $\$ 31.06$ million, respectively.

Likewise, the total revenue for large ethanol enterprise plants is about two times (1.93 times) higher at an average of $\$ 285.7$ million compared with small enterprise plants at $\$ 147.5$ million. Correspondingly, large ethanol enterprise plants net income uptake is 2.38 times higher than small enterprise plants in an average amount of $\$ 6.69$ million compared with large enterprise plants net income average of $\$ 15.93$ million (Table 2). 
Table 2. Comparison of Means of Small and Large Ethanol Plants Financial Performance, U.S., 2009-2014

\begin{tabular}{|l|l|l|l|l|l|l|}
\hline Variables & Small Plants & \multicolumn{3}{l|}{ Large Plants } \\
\hline & Mean & Minimum & Maximum & Mean & Minimum & Maximum \\
\hline $\begin{array}{l}\text { Age (years } \\
\text { in existence) }\end{array}$ & $\begin{array}{l}9.0 \\
(4.26)\end{array}$ & 5.0 & 18.0 & $\begin{array}{l}6.2 \\
(1.36)\end{array}$ & 5.0 & 9.0 \\
\hline $\begin{array}{l}\text { Total Asset } \\
\text { in \$) }\end{array}$ & $\begin{array}{l}82077271 \\
(23550961)\end{array}$ & 44998730 & 139662533 & $\begin{array}{l}153423765 \\
(31880514)\end{array}$ & 98549714 & 222367701 \\
\hline $\begin{array}{l}\text { Total Liability } \\
\text { in \$) }\end{array}$ & $\begin{array}{l}31068978 \\
(22144243)\end{array}$ & 3904658 & 73835530 & $\begin{array}{l}63792558 \\
(45107551)\end{array}$ & 8334254 & 163760357 \\
\hline $\begin{array}{l}\text { Total Revenue } \\
\text { in \$) }\end{array}$ & $\begin{array}{l}147550754 \\
(49035606)\end{array}$ & 18983802 & 300954984 & $\begin{array}{l}285690050 \\
(77834029)\end{array}$ & 99986005 & 419312560 \\
\hline $\begin{array}{l}\text { Total Equity } \\
\text { in \$ }\end{array}$ & $\begin{array}{l}51304113 \\
(15470953)\end{array}$ & 17549447 & 103152157 & $\begin{array}{l}89628232 \\
(34415673)\end{array}$ & 41597000 & 159223561 \\
\hline $\begin{array}{l}\text { Net Income } \\
\text { in \$ }\end{array}$ & $\begin{array}{l}6696294 \\
(15630860)\end{array}$ & -32352643 & 59090503 & $\begin{array}{l}15934752 \\
(28485597)\end{array}$ & -43917042 & 87261674 \\
\hline Subsidy & 23647 & 0.00 & 697000 & $\begin{array}{l}1499894 \\
(6647395)\end{array}$ & 0.00 & 40000000 \\
\hline
\end{tabular}

*Values in parenthesis is the SD of the mean.

Subsidy received by ethanol enterprises in the United States is one of the most contested support to the industry. In this data set the average subsidy received by a large enterprise capacity plants is at $\$ 1.49$ million compared with small enterprise capacity plants at \$23 647 .

The profitability ratio is based on the net income generated for every dollar of equity invested or return of equity. It showed on average that large corn-ethanol enterprise plants registered a return of $10.2 \%$ per dollar of equity invested compared with small enterprise capacity plants at $5.5 \%$ (Table 3). Figure 2 shows the behavior of profitability for large and small ethanol plants. Initially, both sizes of plants had negative profitability. Profitability was growing in 2010 and 2011. However, in 2012 both types of plants experienced decrease in profitability due to drought and high corn prices in later part of 2011. Wu and Ho (1997) found that small firms tend to be more prone to external effects, as is observed from Figure 2. Increase in profitability in the late years is the result of better corn crop and corn prices. Two groups were tested and T-test showed that there is no significant difference in the profitability ratio between small and large size ethanol enterprises.

Asset turnover ratio measured the efficiency of the enterprise to convert asset to generate total revenue. On average, nearly twice of the total revenues were generated from their asset value in both large (1.9619) and small (1.9497) ethanol enterprise plants (Table 3). This suggests that both ethanol enterprise plants showed comparable technology assets to be financially efficient. Statistical comparison using the t-test showed that there was no significant difference between small and large ethanol enterprise plants in asset turnover ratio. 
Table 3. Comparison of Financial Ratios of Small and Large Ethanol Enterprise Plants in the U.S., 2009-2014

\begin{tabular}{|l|l|l|l|l|l|l|l|}
\hline & \multicolumn{2}{|l|}{ Small Plants } & \multicolumn{2}{l|}{ Large Plants } & T-Test Value \\
\hline Ratios & Mean & Min & Max & Mean & Min & Max & $\begin{array}{l}\text { Difference } \\
\text { Small-Large }\end{array}$ \\
\hline $\begin{array}{l}\text { Profitability Ratio (Net } \\
\text { Income/Total Equity) }\end{array}$ & $\begin{array}{l}0.05531 \\
(0.3777)\end{array}$ & -1.8435 & 0.5728 & $\begin{array}{l}0.1019 \\
(0.3231)\end{array}$ & -1.0381 & .57031 & -0.72 \\
\hline $\begin{array}{l}\text { Asset Turn Over } \\
\text { (TotalRevenue/Total Asset) }\end{array}$ & $\begin{array}{l}1.9497 \\
(0.8054)\end{array}$ & 0.1647 & 4.0549 & $\begin{array}{l}1.9619 \\
(0.7106)\end{array}$ & 0.4496 & 3.5005 & 0.11 \\
\hline $\begin{array}{l}\text { Leverage Ratio (Total } \\
\text { Liability/Total Equity) }\end{array}$ & $\begin{array}{l}0.7214 \\
(0.6518)\end{array}$ & 0.0699 & 2.7939 & $\begin{array}{l}1.0008 \\
(1.0046)\end{array}$ & 0.0523 & 3.2894 & $2.28^{* *}$ \\
\hline $\begin{array}{l}\text { Liquidity Ratio (Current Asset } \\
\text { /Current Liability) }\end{array}$ & $\begin{array}{l}2.3499 \\
(1.4916)\end{array}$ & 0.1675 & 6.5170 & $\begin{array}{l}2.1893 \\
(1.4896)\end{array}$ & 0.2463 & 9.0194 & -0.50 \\
\hline $\begin{array}{l}\text { Operating Margin Ratio } \\
\text { (Operating Income/Total } \\
\text { Revenue) }\end{array}$ & $\begin{array}{l}0.0447 \\
(0.0808)\end{array}$ & -0.1766 & 0.2219 & $\begin{array}{l}0.0552 \\
(0.0958)\end{array}$ & -0.2005 & 0.2608 & 0.93 \\
\hline
\end{tabular}

Note: Values in parenthesis is the SD of the mean.

Significance:* significant@0.10 level; ** significant @0.05 level; *** significant @.01 level.

The liquidity ratio or the current ratio measures the ability of the enterprise to pay current debt from its current asset. Data shows that both ethanol enterprises have more than twice $(2 \mathrm{x})$ of its current financial asset value to cover for its current liability (Table 3). At the liquidity ratio of 2.19:1 for large enterprise and 2.35:1 for small enterprise, it indicated that most ethanol enterprises were building a fundamental current asset base to cover for current risks liability. Significantly, the data shows that ethanol enterprises had not reached a negative liquidity ratio. A T-test indicated that there was no significant difference between small and large enterprises in the liquidity ratio performance.

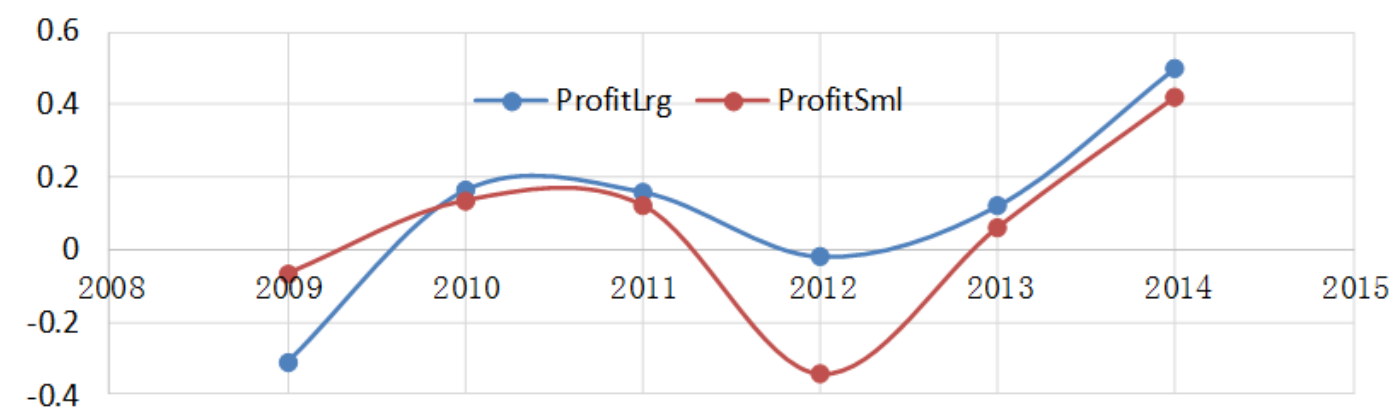

Figure 2. Trends of Profitability Ratio in Small and Large Ethanol Enterprise Plants, U.S., 2009-2014

Presentation data from Christianson and Associates (2015) shows the general US ethanol plants have a current ratio (current assets/current liabilities) at an average of 2.09:1 from 2010 to 2015.

The leverage ratio assesses the debt-to-equity performance of the ethanol enterprise. Total 
liability is expected to decline against its own equity as ethanol enterprise plants pay-off its liability from the implementation of an appropriate financial management strategies. Data shows that large enterprise plants have an average leverage ratio of 1.0008:1 (Table 3). This means that every dollar of equity is guaranteed to cover the total liability for large enterprise ethanol capacity plants. For small capacity enterprise plants, the leverage ratio is at the level of $0.7214: 1$, which suggests that $30 \%$ of the equity value is free from total liability. On average, small capacity ethanol enterprises have lower total liability to roll-over the plant operation than a large enterprise. However, the trends on leverage ratio for large and small ethanol enterprise plants are showing a decline over the period at 1.60 and 1 is to 0.3 and 0.23 , respectively (Figure 3). Over all, this characteristic explains the statistically significant difference between large and small ethanol enterprises in the leverage financial performance.

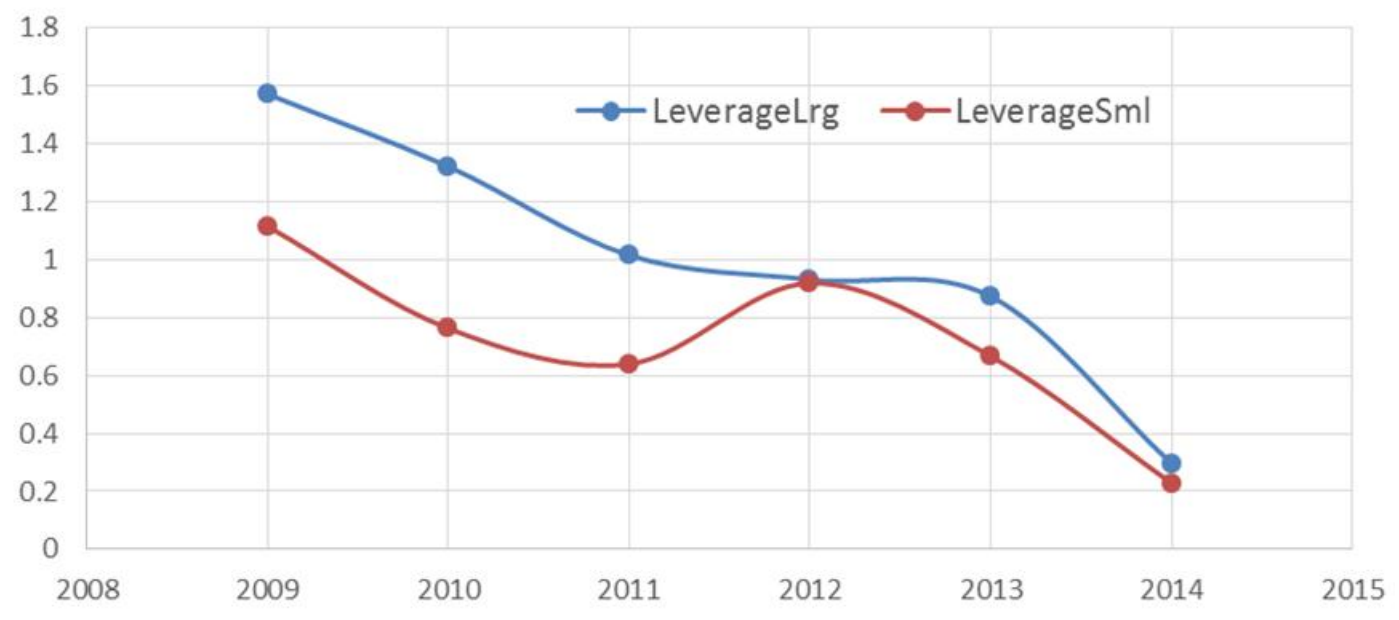

Figure 3. Trends of Leverage Ratio in Small and Large Ethanol Enterprise Plants, 2009-2014

Operating margin ratio measures the efficiency of the plant operation. It is determined by the operating income over total revenue generated by the plant. Data shows a $5.52 \%$ of the total revenue generated operating income for a large ethanol enterprise, and $4.47 \%$ for small enterprise capacity (Table 3). T-test showed that there was no significant difference between the large and small enterprise plants. This result suggests that both enterprise plants use similar corn-ethanol cost efficient technologies in plant operation to generate operating income from ethanol and its co-products.

\subsection{Factors Affecting Profitability of the Corn-Based Ethanol Enterprises in the U.S.}

Regression analysis using the ratio of profitability as dependent variable responded significantly to the price of corn, subsidy, efficiency, liquidity, and leverage variables. However, the analysis showed that plant size, age, and operating margin ratio do not exhibit a significant impact on the profitability ratio (Table 4).

The resulting econometric model has significant explanatory power of 45.6 percent and adjusted $\mathrm{R}^{2}$ of a 38.7 percent. The model is tested for autocorrelation. Durbin-Watson value of 2.21 at a $1 \%$ of significance level suggesting the absence of autocorrelation. Detecting the 
presence of collinearity using the VIFs shows no significant effect on the variables used in the model. The highest VIF of two is detected between efficiency variable and profitability. Breusch-Pagan test on the effect of heteroscedasticity supports the null hypothesis of no significant presence of heteroscedasticity. The f-value of regressed squared residuals on all explanatory variables show no statistical significance $(\mathrm{F}=0.244)$ in this model.

Table 4. Regression Analysis of Corn-based Ethanol Enterprises in the U.S.

\begin{tabular}{|l|l|l|l|l|}
\hline Label & Parameter Estimate & Standard Error & T Value & $\operatorname{Pr}>|t|$ \\
\hline Intercept & 0.2883 & 0.2196 & 1.31 & 0.1941 \\
\hline Age & -0.0062 & 0.0081 & -0.76 & 0.4444 \\
\hline CornPrc & $-0.0474^{1 / 2 *}$ & 0.0361 & -1.31 & 0.1937 \\
\hline DumSz1 & -0.0375 & 0.0773 & -0.48 & 0.6295 \\
\hline OpMar & 0.8915 & 2.0461 & 0.43 & 0.6645 \\
\hline AsTurnO & $0.0983^{*}$ & 0.0511 & 1.92 & 0.0593 \\
\hline Leverage & $-0.4695^{* *}$ & 0.2008 & -2.47 & 0.0161 \\
\hline Liquidity & $1.7681^{* * *}$ & 0.4395 & 4.02 & $<0.000$ \\
\hline Subsidy & $1.37 \mathrm{E}-8^{*}$ & $7.87 \mathrm{E}-9$ & 1.75 & 0.0844 \\
\hline R2 & 0.456 & & & \\
\hline Adjusted-R2 & 0.387 & & & \\
\hline F-value & 6.60 & $\mathrm{p}$-value & $3.1 \mathrm{E}-6$ & \\
\hline
\end{tabular}

Note: $* * *$ significant at 0.01 level; $* *$ significant at 0.05 level; *significant at 0.10 level, ${ }^{1 / 2 *}$ significant at 0.20 level

Price of corn demonstrated a significant negative impact on the profitability ratio. Data indicated that, as the price of corn increases by $1 \$ / \mathrm{bu}$, profitability ratio decreases by $0.047 \%$. This is consistent with the expectations, since price of a corn is one of the main costs in the ethanol production process.

The leverage ratio provided a highly significant and negative effect on the profitability ratio. An increase of $1 \%$ in the leverage ratio decreases profitability ratio by $\approx 0.47 \%$ points. Reduction of total liability in the leverage ratio contributes to equity portion of the profitability ratio and builds up asset value of the enterprise. Liability takes off the pressure on capital infusion in the operation of the ethanol plant enterprises. Though the magnitude is relatively small it significantly signals that liability reduction contributes to the increase of profitability ratio.

Liquidity has a positively significant impact on profitability. Numbers in table 3 showed a strong liquidity base across all plants, as an ability to cover current risks by converting financial assets to pay its liabilities. Model results state that if liquidity increases by $1 \%$ profitability of an ethanol plant increases by $1.78 \%$. Result estimates a highly significant and large contribution of leverage to the profitability of an ethanol plant. 
Subsidy received by ethanol enterprises during the study period show significant but very marginal impact on the profitability. Earlier results in this study indicated that large plants received higher subsidy amounts than small capacity plants. Subsidy received by the ethanol enterprises is expected to boost the capital structure in the asset balance of the financial statement. This result either suggests that the impact of subsidies received by ethanol enterprise plants is not substantial to contribute more on the profitability ratio as subsidy was not uniformly received by these enterprises, or the data is not sufficient to make a definitive conclusion of its association with profitability ratio.

Plant size has no significant impact on the profitability of an ethanol plant. Data in table 3 shows some statistical differences in leverage between the two sizes, however regression results show that ethanol production is a profitable enterprise independently of plant size.

Asset turnover ratio significantly and positively impacts profitability. An increase of $1 \%$ in assets turnover increases profitability by $\approx 0.1 \%$. This relationship shows efficient generation of internal income from plant's operation. Recent technical data of corn conversion to ethanol has improved from an average of 2.65 gallons per bushel of corn in 2005 (Bothast and Schlicher) to 3.36 gallons per bushel in 2014 , or increased by $27 \%$ and added 0.71 ethanol gallons more since 2005 (NCGA, 2014). For every dollar per bushel of corn utilized in the operation, the corn is efficiently "squeezed" or converted efficiently to generate ethanol and its co-products. This suggests that technical cost efficiency contributes the profitability ratio.

In addition, Figures 4 and 5 show the annual price trends of corn, ethanol and dried distillers' grain soluble (DDGS). The trends show that as the price of corn moves upward and ethanol price remains relatively constant, and the price of DDGS also moves upward. In a typical 100 MGY corn-based ethanol, it produced 90 MGY of ethanol and about 230,000 tons of dried grains soluble (DDGS). Using the average 2014 prices of ethanol at $\$ 2.343 /$ gal and $\$ 157.69 /$ ton for DDGS, ethanol generated $85 \%$ of the total revenue and $15 \%$ revenue from the DDGS. When the

Price of ethanol is down, the share of DDGS revenue contribution is compensating the ethanol revenue loss from the price changes. This trend suggests that DDGS price contributes significantly to the over-all revenue of the enterprise when ethanol price is down, making corn price variable as a total revenue generator.

An emerging ethanol enterprise has to take-off in massive production is the cellulosic ethanol enterprise. Current search on the operation of the cellulosic ethanol enterprise in the U.S. shows the existence of 3 operational plants. One is operated by DuPont, a 30-MGY capacity plant in Nevada, Iowa. The DuPont plant uses corn stover as feedstock. The second is the Abengoa plant in Hugoton, Kansas. It is a 25-MGY capacity plant and operated by a 1,000-ton daily feedstock of corn stover and wheat straw. The third plant is operated by Sioux Falls plants which is managed by the POET and the Royal DSM in Emmetsburg, Iowa. It is a 25-MGY capacity plant and operated by 770 tons per day of corn cobs, husk, and stalks (Gies, 2014). The Bloomberg 


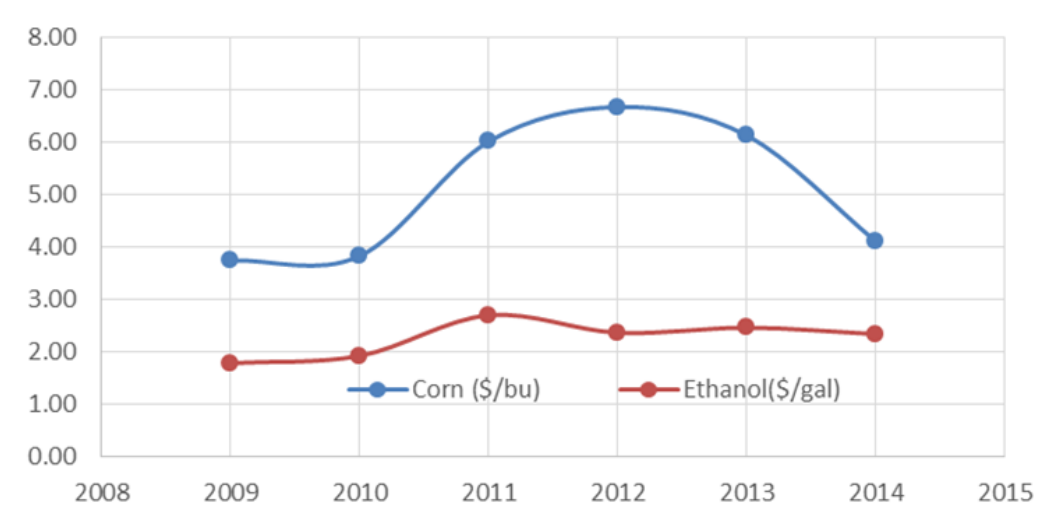

Figure 4. Trends of Corn Price and Ethanol Price, U.S., 2009-2014

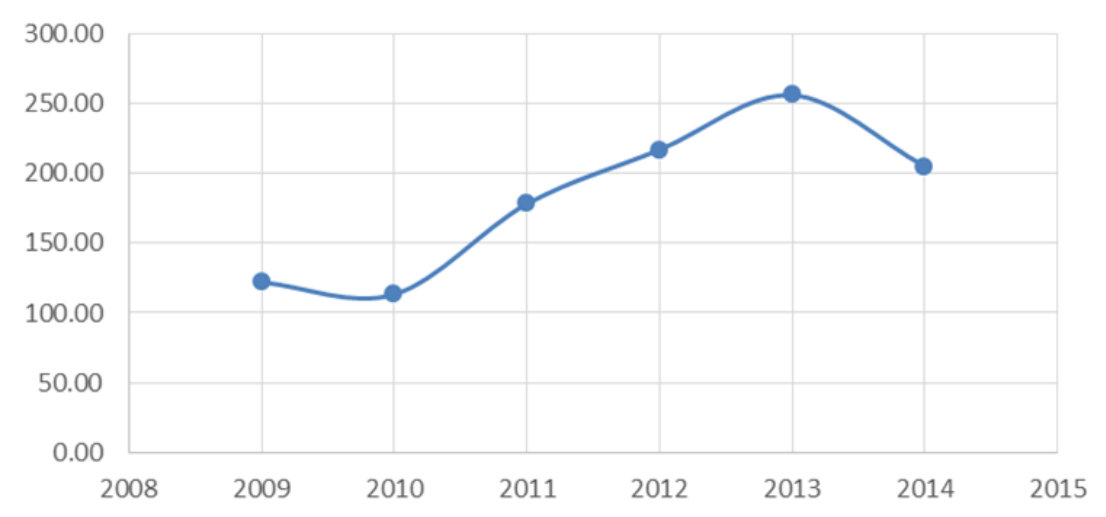

Figure 5. Trend of Corn-based Dried Distiller's Grain Soluble, U.S., 2009-2014(\$/ton)

New Energy Survey stated that it cost $40 \%$ more to produce ethanol from cellulosic materials compared with the existing corn-based ethanol (Isola, 2013; Voegele, 2013). An intensive search of these companies' financial operations to compare with the corn-based ethanol plants was done, but data were not available as its financial statements were consolidated to its respective parent companies.

According to the PEW Center on Global Climate Change (2009), one of several obstacles to the development of the cellulosic ethanol is cost: high capital investment ( $\$ 375$ million for a 50-MGY which is 6-fold higher than corn-ethanol of the same size) and the uncertain feedstock cost which is estimated between $\$ 25$ and $\$ 50$ per dry ton.

Converging information on the cellulosic ethanol production and findings from the financial data of the corn-based ethanol production indicates that the financial success of the cellulosic ethanol enterprise maybe associated with the efficiency of its core operation and the total revenue generating capacity of its co-products. With the uncertainty of feedstock cost, the ability of the plant to generate other revenues from its co-products, like the cellulosic material stillage may improve operating income by using it as its own biomass feedstock to generate its own energy or improve total revenue by selling its stillage as a biomass to other bio-refinery or energy refinery. Stillage is a co-product of the cellulosic process. It has a high value when processed as a biomass material for boiler to generate steam and as a biomass 
feedstock for coal burning facility (Wilkie et al., 2000). Unfortunately, stillage is not a publicly traded or marketed. Thus, as the price of ethanol varies over the time, the quality and value of stillage it produces is an option to generate additional operating income and/or contributes to the total revenue of the cellulosic ethanol plant to be more financially viable.

\section{Conclusion}

The analyses of financial characteristics of the corn-based ethanol enterprises show a viable performance of ethanol industry. All twelve examined ethanol plants provided an evidence of positive financial dynamics. Three out of four financial explanatory variables show significance in explaining profitability, these are - leverage, liquidity, and asset turnover. As leverage ratio declines over time, it indicates higher return of investment will be deposited to the investors' accounts.

The positive return of investment is attributed by the economic cost/technical efficiency of the corn-ethanol technologies. The technical efficiency as indicated by the financial ratio of asset turnover has shown signs of technology improvements over time. As the technology improves in extracting ethanol from corn, it also brings improved quality of its co-products that contributes to the total revenue. As ethanol is considered a commodity, it is suggested that its DDGS co-products be differentiated with quality and price premium to cushion revenue loss from the ethanol price changes.

Another attribute of all ethanol plants is a strong risk aversive behavior in financial operations. Even though it may not be possible to control fluctuations in the corn price market, all plants exhibit a strong ability to cover current risks by converting financial assets to pay its liabilities. Subsidies received by ethanol enterprises show significant but very small impact on the profitability. This too assures financial stability of operations of ethanol plants.

Likewise, this study suggests to the ethanol industry for the establishment of a financial benchmark of its performance to gauge how far the industry has improved overtime.

Findings of this study suggest similar consideration that may affect the viability of the advanced cellulosic enterprise to be financially feasible. The value-addition from the raw materials of switchgrass, sugar bagasse, corn stover, and other cellulosic materials to its resulting stillage co-product is significant to consider to be utilized in the operation of plant and/or for revenue generation. Technology investment for a more efficient process or processes of ethanol extraction from cellulosic materials is a valuable pathway to increase cellulosic ethanol production, but the value-addition and utilization of its co-products can greatly improve its sustained economic financial success.

\section{Acknowledgement}

This study was made possible by grants from the Fulbright-Philippines Agriculture Scholarship Program (FPASP) for Advanced Research in Agriculture of the Fulbright Commission in the Philippines and the Department of Agricultural and Applied Economics of the Texas Tech University in Lubbock, Texas. 


\section{References}

Bothast, R. J., \& Schicher, M. A. (2005). Biotechnological process for conversion of corn into ethanol. ApplMicrobiolBiotechnol, 67, 19-25. https://doi.org/10.1007/s00253-004-1819-8

Cai, X., \& Stiegert, K. W. (2014). Market Analysis of Ethanol Capacity. International Food and Agribusiness Management Review, 14(1), 83-93.

Christianson \& Associates. (2015). Cash Flow Overview: Ethanol Plants in 2014-2015. Paper presented at the 2015 Biofuels Financial Conference Agenda, Embassy Suites, Bloomington, MN, 24-25 June.

Clarke, B. M. (2009). Taking the Entity's Temperature: What financial statements can tell about the enterprise? Family Advocate, 31(4), 28-33.

Dewenter, K. L., \& Malesta, P. H. (2001). State-owned and Privately-owned Firms: An Empirical Analysis of Profitability, Leverage and Labor Intensity. The American Economic Review, 91(1), 320-334. https://doi.org/10.1257/aer/91.1.320

Eidman, V. T. (2007). The Evolving Ethanol Industry in the U.S. Selected paper presented under The Economic Impact of the Ethanol Development session of the Canadian Agricultural Economics Society, Portland, Oregon, 30 July.

Fatal, Y. S., \& Thurman, W. N. (2014). The Response of Corn Acreage to Ethanol Siting. Journal of Agricultural and Applied Economics 46(2), 157-171.

https://doi.org/10.1017/S1074070800000717

Farm Financial Standard Council. (2015). The Financial Guidelines for Agricultural Production (January 2015, electronic copy).

Feng, H., \& Babcock, B. (2008). Impact of Ethanol on Planted Acreage in Market Equilibrium. Working paper 08-WP472, Center for Agricultural and Rural Development, Iowa State University.

Gies, E. (2014). For Cellulosic Ethanol Makers, The Road Ahead is Still Uphill. Yale Environment 360, 03November. [Online] Available:

http://e360.yale.edu/content/print.msp?id=2821 ( February 22, 2016).

Hisham, S. E., \& Johnson, J. D. (1998). Determinants of Financial Performance of Commercial Dairy Farms. Economics Research Service, U.S. Department of Agriculture, Technical Bulletin No. 1859 (July). [Online] Available at:

www.ers.usda.gov/media/930006/tb1859.pdf_(January 18, 2016).

Isola, J. (2013). Cellulosic Ethanol Heads for Cost Competitiveness by 2016. The Bloomberg New Energy Finance, 12March. [Online] Available:

http://about.bnef.com/press-release/cellulosic-ethanol-heads-for-cost-competitiveness-by-201 6

Jablonsky, S. F., \& Barsky, N. P. (2001). The Manager's Guide to Financial Analysis, $2^{\text {nd }}$.ed.New York: John Wiley \& Sons. 
Johnson, D. E., Davis, S. B., \& Albright, T. L. (2009). Examining the Relationship between Employee Attitudes and a Firm's Financial Performance: A Theoretical and Framework and Causal Investigation. Journal of Managerial Issues, 21(3), 367-382.

Lerman, Z., \& Parliament, C. (1991). Size and industry effects in the performance of agricultural cooperatives. Agricultural Economics, 6(1), 15-29.

https://doi.org/10.1016/0169-5150(91)90013-B

Lev, B. (1969). Industry averages as targets for financial ratios. Journal of Accounting Research, 7, 290-299. https://doi.org/10.2307/2489971

Miller, J. C., \& Coble, K. H. (2011). Incentives Matter: Assessing the Biofuel Policies in the South. Journal of Agricultural and Applied Economics, 43(3), 413-421.

https://doi.org/10.1017/S1074070800004405

Mirer, T. W. (1995). Econometric Statistics and Econometrics, $3^{\text {rd }}$.ed. NJ: Prentice Hall.

National Corn Growers Association (NCGA). (2014).'How much ethanol can come from corn?" [Online] Available: www.cie.us/document/HowMuchEthanol.pdf (February 5, 2016).

PEW Center. (2009). Climate Tech Book: Cellulosic Ethanol. The PEW Center on Global Climate Change. November: 1-8. [Online] Available:

http://www.c2es.org/docUploads/Cellulosic-ethanol-11-09.pdf

Placencia, J., Welge, B., \& Oliver, D. (1989). Financial Accounting Guide for Small Business. OR: Oasis Press.

Renewable Fuels Association. (2014). Industry Statistics. [Online] Available: http://ethanolrfa.org/statistics

Schmit, T. M., Luo, J., \& Tauer, L. W. (2009). Ethanol Plant Investment Using Present Value and Real Options Analyses, Biomass and Bioenergy, 33(10), 1442-51.

https://doi.org/10.1016/j.biombioe.2009.06.010

Smith, D. J., Trechter, D., \& Splett, N. (2003). The Contribution of Financial Management Training and Knowledge to Dairy Farm Financial Performance. Review of Agricultural Economics, 26(1), 132-147. https://doi.org/10.1111/j.1467-9353.2003.00166.x

Soboh, R. A. M. E., Lansink, A. O., Giesen, G., \& Van Dijk, G. (2009). Performance Measurement of the Agricultural Marketing Cooperatives: The Gap between Theory and Practice. Review of Agricultural Economics, 31(3), 446-469.

https://doi.org/10.1111/j.1467-9353.2009.01448.x

Taxpayers for Common Sense (TCS). (2015). Understanding Federal Subsidies for Biofuels and Biomass Industries. The Taxpayers for Common Sense, September. [Online] Available: http://www.taxpayer.net (December 8, 2015).

Tyner, W. E., \& Quear, J. (2006). Comparison of a Fixed and Variable Corn Ethanol Subsidy. Choices, 21(3), 199-202. 


\section{Macrothink}

Business and Economic Research ISSN 2162-4860 2017, Vol. 7, No. 1

Tyner, W. E. (2007). U.S. Ethanol Policy-Possibilities for the Future. Bioenergy ID-324-W, Purdue University Extension.

Tyner, W. E. (2013). The Renewable Fuel Standard-Where Do We Go From Here. Choices, 28(4), 1-5.

U.S. Department of Agriculture. (1994). Financial Performance of U.S. Commercial Farms, 1991-94.Farm Business Economics Branch, Rural Economy Division, Economic Research Service, Rep.751, Washington, DC.

U.S. Department of Energy. (2010). Current State of US Ethanol Industry. Washington, DC. [Online] Available:

http://eere.energy.gov/bioenergy/pdfs/current_state_of_the_US-ethanol_industry.pdf

Wang, G. C. S., \& Akabay, C. K. (1995). Autocorrelation: Problems and Solutions in Regression Modeling. Journal of Business Forecasting Winter 1994-95:18-26.

Westcott, P. C. (2007). Ethanol Expansion in the United States: How Will the Agricultural Sector Adjust? Washington, DC: U.S. Department of Agriculture, ERS, Rep. FDS-07D-01, May. [Online] Available: http://www.ers.usda.gov/Publications/FDS/2007/05May/FDS07D01, accessed (December 29, 2014)

White, G. I., Sondhi, A. C., \& Fried, D. (1998). The Financial and Use of Financial Statements, $2^{\text {nd }}$. ed. NY:John Wiley $\&$ Sons.

Wilkie, A. C., Riedesel, K. J., \& Owens, J. M. (2000). Stillage characterization and anaerobic treatment of ethanol stillage from conventional and cellulosic feedstock. Biomass and Bioenergy, 19, 63-102. https://doi.org/10.1016/S0961-9534(00)00017-9

Woelfel, C. J. (1994). Financial Statement Analysis. Chicago: Probus Publishing Company.

Wu, C., \& Ho, S. K. (1997). Financial Ratio Adjustment: Industry-Wide Effects of Strategic Management. Review of Quantitative Finance and Accounting, 9, 71-88.

https://doi.org/10.1023/A:1008231027420

Voegele, E. (2013). Survey: cellulosic ethanol will be competitive by 2016. Ethanol Producer Magazine, 18March. [Online] Available:

http://ethanolproducer.com/articles/9658/survey-cellulosic-ethanol-will-be-competitive-by-20 16

Yee, C. Y., \& Cheah, C. Y. J. (2006). Fundamental Analysis of Profitability of Large Engineering and Construction Firms. Journal of Management in Engineering, 22(4), 203-210. https://doi.org/10.1061/(ASCE)0742-597X(2006)22:4(203)

\section{Copyright Disclaimer}

Copyright for this article is retained by the author(s), with first publication rights granted to the journal.

This is an open-access article distributed under the terms and conditions of the Creative Commons Attribution license (http://creativecommons.org/licenses/by/3.0/). 